\title{
Isolation of Pseudomonas flurescens from Rhizosphere of Faba Bean and Screen Their Hydrogen Cyanide Production Under in Vitro Stduy, Ethiopia
}

\section{Fekadu Alemu}

Department of Biology, College of Natural and Computational Sciences, Dilla University, Dilla, Ethiopia

Email address:

fekealex@gmail.com

\section{To cite this article:}

Fekadu Alemu. Isolation of Pseudomonas flurescens from Rhizosphere of Faba Bean and Screen Their Hydrogen Cyanide Production Under in Vitro Stduy, Ethiopia. American Journal of Life Sciences. Vol. 4, No. 2, 2016, pp. 13-19. doi: 10.11648/j.ajls.20160402.11

Received: June 11, 2015; Accepted: June 26, 2015; Published: March 23, 2016

\begin{abstract}
Hydrogen cyanide is a highly toxic volatile compound which interferes with the cellular respiration by inhibiting the cytochrome oxidase enzyme in mitochondria. Root area of crops were consisting several bacteria that may have beneficial aspects. The objective of this study was to investigate the qualitative capability of hydrogen cyanide production by Pseudomonas fluorescens species isolates. Isolation of Pseudomonas fluorescens isolates were carried out on King's B medium. Twelve Pseudomonas fluorescens species were isolated from the Rhizosphere of Fabaceae family namely faba bean screened for the production of hydrogen cyanide. For the production of hydrogen cyanide, Pseudomonas fluorescens isolates were streaked into King's B agar plates supplemented with glycine. Total of Pseudomonas fluorescens isolates had a potential to produce hydrogen cyanide. Therefore, these isolated can be used as a biological control against plant pathogen microbes.
\end{abstract}

Keywords: Biological Control, Faba Bean, Hydrogen Cyanide, Pseudomonas fluorescens

\section{Introduction}

Plant growth promoting rhizobacteria are known to rapidly colonize the rhizosphere and suppress soil borne pathogens at the root surface (Rangajaran et al., 2003). These bacteria are generated mainly by the production of indole-3-acetic acid (IAA), siderophores, and some well-known antibiotics (Nagarajkumar et al., 2004) and hydrogen cyanide (HCN) (Voisard et al., 1989) production. Biocontrol agents exert a protective effect on the roots through antagonism against phytopathogenic fungi and bacteria (Dwivedi and Johri, 2003). Fluorescent pseudomonads exhibit diverse mechanisms of biocontrol which include antibiosis, HCN production, siderophore production, competition for space and nutrients and induced systemic resistance (Shivakumar, 2007).

Some Pseudomonas has been reportedly characterized as root colonizers of several food crops that evade pathogenesis against multiple pathogens (Bano and Mussarrat, 2003). Cyanide toxicity to a wide spectrum of organisms is as a consequence of its ability to form complex with metals $\left(\mathrm{Fe}^{2+}\right.$, $\mathrm{Mn}^{2+}$ and $\mathrm{Cu}^{2+}$ ) that are functional groups of many enzymes, inhibiting processes like the reduction of oxygen in the cytochrome respiratory chain, electron transport in the photosynthesis and the activity of enzymes like catalase, oxidase (Cheeke, 1995; McMahon et al., 1995). An organism can only metabolize cyanide only when it possesses a biodegradable pathway to convert cyanide into an assimilative product $\left(\mathrm{NH}^{4+}\right)$, cyanide resistance mechanism and a system for taking up $\mathrm{Fe}^{3+}$ from the medium (siderophores). Although some organisms synthesize cyanide, a greater number are capable of cyanide biodegradation. The existence of pathways in these organisms allowed for the development of biotechnologies to degrade cyanide compounds in industrial waste streams (Ebbs, 2004). The lethal single dose of cyanide for vertebrates has been reported to be between the ranges of 35$150 \mu \mathrm{mol} / \mathrm{kg}$, though much higher amounts of HCN can be tolerated if consumed over a long period (Zagrobelny et al., 2008). Cyanide is highly toxic for most living organisms because it forms very stable complexes with transition metals that are essential for protein function, i.e., iron in cytochrome oxidase (Luque-Almagro et al., 2005).

$\mathrm{HCN}$ first inhibits the electron transport and the energy supply to the cell is disrupted leading to the death of the 
organisms. It inhibits proper functioning of enzymes and natural receptors reversible mechanism of inhibition (Corbett, 1974) and it also known to inhibit the action of cytochrome oxidase (Gehring et al., 1993). HCN is produced by many rhizobacteria and is postulated to lay a role in biological control of pathogens (Defago et al., 1990). Production of $\mathrm{HCN}$ by certain strains of fluorescent pseudomonads has been involved in the suppression of soil borne pathogens (Voisard et al., 1989). Pseudomonas fluorescens HCN inhibited the mycelial growth of Pythium in vitro (Westsleijn, 1990).

$\mathrm{HCN}$, a volatile metabolite is thought to play a major role in biological control of some soil borne diseases (Siddiquis et al., 2006). HCN inhibits the electron transport thereby energy supply to the cells is disrupted leading to the death of the organism. It affects the proper functioning of the enzymes and natural receptors by reversible mechanisms of inhibition (Corbett, 1974). It is also known to inhibit the action of cytochrome oxidase (Gehring et al., 1993) as indicated in fig 1.

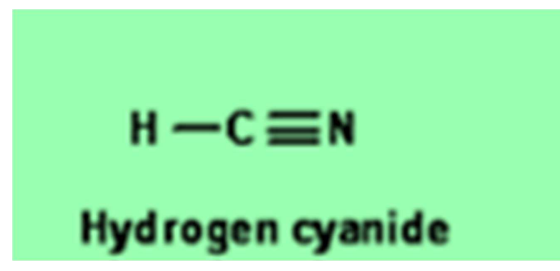

Figure 1. Hydrogen cyanide (HCN) structure (Raaijmakers et al., 2002).

HCN production by $P$. fluoresens, $P$. aeruginosa, Chromobacterium violaceum, and Rhizobium isolates was reported by many researchers (Siddiqui et al., 2003; Antoun et al., 1998). P. fluorescens CHAO is an aerobic, rootcolonizing biocontrol bacterium that protects several plants from root diseases caused by soil borne fungi (Voisard et al., 1989; Voisard et al., 1994). Cyanide producing strain CHA0 stimulated root hair formation, indicating that the strain induced altered plant physiological activities. Exposing plants to the volatile metabolites of antagonist causes a significant increase in peroxides activity, which may contribute to induction of disease resistance (Wangi et al., 2002; Keel et al., 1989; Sacherer et al., (1994) developed a disease assay for Thielaviopsis basicola on tobacco using $\mathrm{Fe}$ rich clays, which were conducive to biocontrol by strain CHA0.

The release of HCN by rhizospheric bacteria into the soil can be toxic to subterranean animals and phytopathogenic organisms (Guo et al., 2007). Microbial production of HCN has been reported as an important antifungal trait to control root infecting fungi (Ramette et al., 2003). Production of HCN by Pseudomonads is associated with biological control of the black root rot of tobacco, but other workers observed that it can have a detrimental effect on plant growth (O'Sullivan and O'Gara, 1992). This study help to identify biocontrol agents for control of crop pathogen, which can be easily and stably, integrated into the existing production practices. Pseudomonas fluorescens strain possessing multiple mechanism of broad spectrum antagonism which can be explored as one among the best biocontrol agent against phytopathogens. The present study was designed to isolate Pseudomonas fluorescens from rhizosphere of healthy faba bean were screened to investigate the qualitative capability of their in hydrogen cyanide production.

\section{Materials and Methods}

\subsection{Soil Sample Collection}

Soil Sample Collection

Rhizospheric soil samples were collected in an envelope from fields growing faba bean (Vicia faba L.) from five locality area of North Showa of Oromeia Regional state of Salele Zone, Ethiopia as shown in fig 2. The soils were brought to Mycology Laboratory, Addis Ababa University.

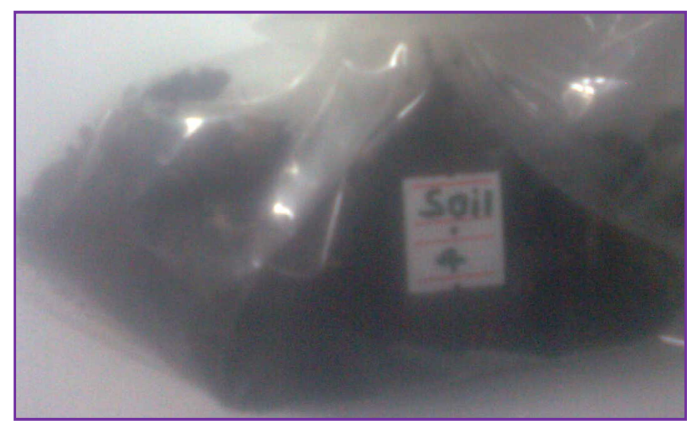

Figure 2. Soil samples.

\subsection{Isolation of Pseudomonas fluorescens}

Ten gram (10 g) of rhizosphere soil sample was suspended in $90 \mathrm{ml}$ of sterile distilled water. Samples were serially diluted up to $10^{-2}$ and $0.1 \mathrm{ml}$ of sample was spreaded on King's B medium plates (King et al., 1954) incubated at $28^{\circ} \mathrm{C}$ for $48 \mathrm{~h}$. After incubation the plates were exposed to UV light at $365 \mathrm{~nm}$ for few seconds and the colonies exhibiting the fluorescence were picked up and purified on King's B medium plates. Twelve strains of P. fluorescens were isolated and they were designated as Pf 1 up to Pf 12 for further studies as indicated in fig 3 .

\subsection{Assay for Hydrogen Cyanide (HCN) Production}

Hydrogen cyanide production was assayed by the method suggested by Castric (1977) and Lorck (1948). For the production of HCN, Pseudomonas fluorescens isolates were streaked into King's B agar plates supplemented with glycine $(4.4 \mathrm{~g} / \mathrm{l})$. After this, petriplates were inverted and a piece of filter paper impregnated with $0.5 \%$ picric acid and $2 \%$ of sodium carbonate was placed on the lid. Petri plates were sealed with parafilm and incubated at $28^{\circ} \mathrm{C}$ for $96 \mathrm{~h}$. Production of cyanide was determined by a color shift from yellow to orange in the filter paper (Castric, 1975). Detection of HCN production was performed by the method of Bakker and Schippers (Bakker, and Schippers, 1987). Production of cyanide was determined by a color shift from yellow to orange in the filter paper (Castric, 1975). 


\section{Result and Discussion}

\subsection{Isolation of Pseudomonas fluorescens}

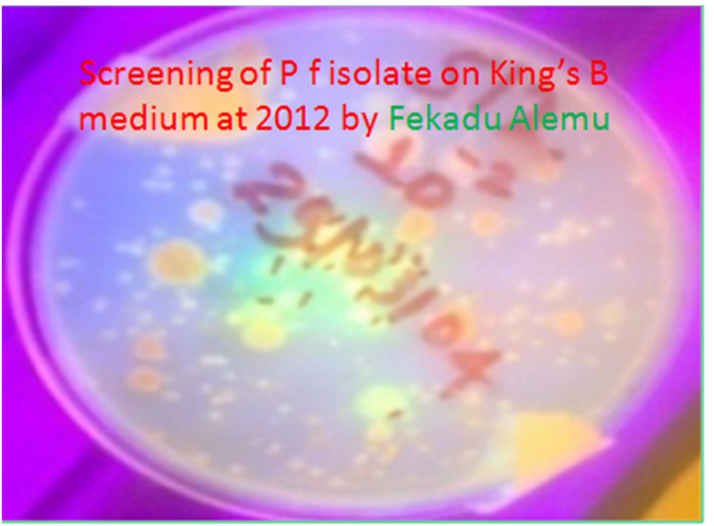

Figure 3. Pseudomonas fluorescens was isolated based on their pigment production under UV light at $365 \mathrm{~nm}$.
During this research study, 12 Pseudomonas fluorescens were isolated from rhizospheric soil of healthy faba bean from five Kebales of Salale zone of Oromiya Region on King's B medium and observed under UV light at $365 \mathrm{~nm}$ for few seconds and pigment producer was screened as indicated fig 3. Then it was purified again on same medium and observed under UV light as shown in fig 4. All the rhizospheric isolates were named as Pseudomonas fluorescens isolate 1= P f1, Pseudomonas fluorescens isolate $2=\mathrm{P}$ f2, Pseudomonas fluorescens isolate $3=\mathrm{P}$ f3, Pseudomonas fluorescens isolate $4=\mathrm{P}$ f4, Pseudomonas fluorescens isolate 5=P f5, Pseudomonas fluorescens isolate $6=\mathrm{P}$ f6, Pseudomonas fluorescens isolate $7=\mathrm{P} \quad \mathrm{f} 7$, Pseudomonas fluorescens isolate $8=\mathrm{P}$ f8, Pseudomonas fluorescens isolate 9=P f9, Pseudomonas fluorescens isolate $10=\mathrm{P} \mathrm{f} 10$, Pseudomonas fluorescens isolate $11=\mathrm{P} \mathrm{fl1}$, Pseudomonas fluorescens isolate $12=\mathrm{P}$ f12, and maintained on Nutrient Agar slants for further testing.
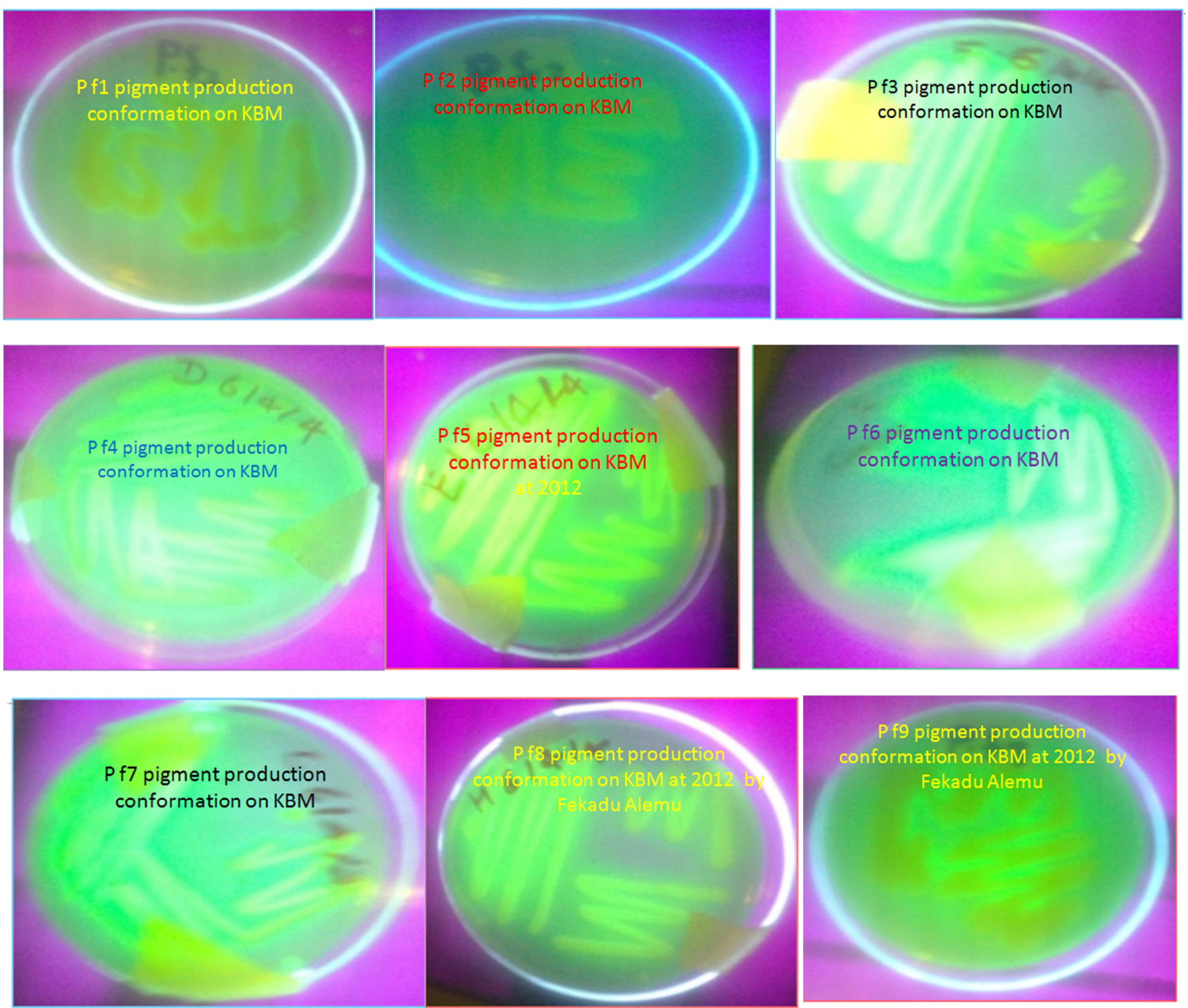

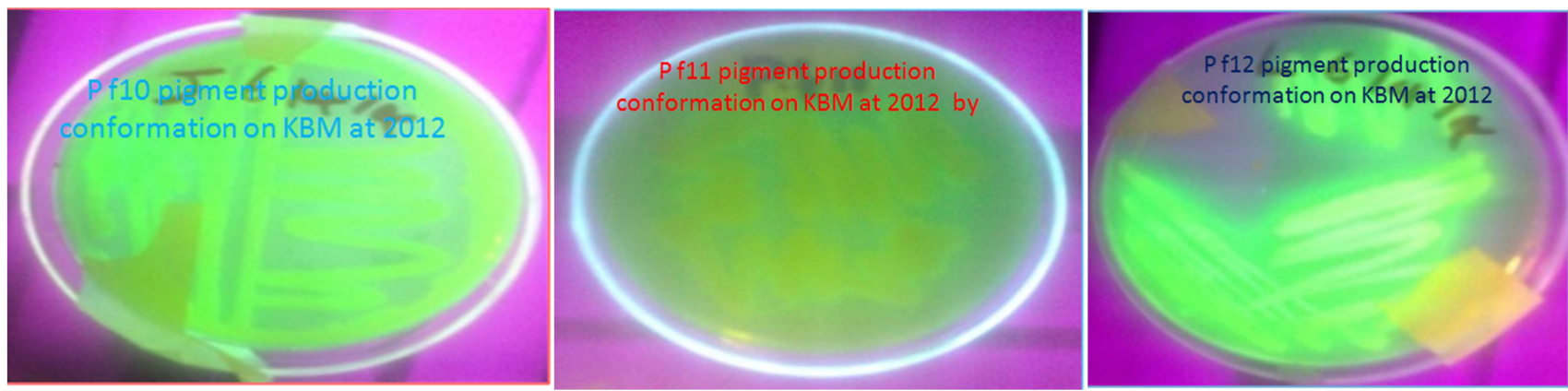

Figure 4. Pseudomonas fluorescens isolates was confirmed again under UV light at $365 \mathrm{~nm}$.

\subsection{Assay for Hydrogen Cyanide Production}

In this study, the Pseudomonas fluorescens isolates exhibited the plant growth promoting traits like Hydrogen cyanide production. Hydrogen cyanide production was tested to all Pseudomonas fluorescens isolates as well as was determined by a color shift from yellow to orange in the filter paper as shown in fig 5 . Hence, they have been advocated as biocontrol agents. Similarly, Plant growth promoting rhizobacteria colonize roots of plant and promote plant growth and development through a variety of mechanisms. The exact mechanism by which Plant growth promoting rhizobacteria stimulate plant growth is not clearly known. However, the mechanisms of suppression of deleterious organisms are through HCN release (Voisard et al., 1989) and competitive colonization of plant roots (Weller, 1985). Four of the six plant growth promoting rhizobacteria strains that induced systemic resistance in cucumber against Colletotrichum orbiculareproduced HCN (Wei et al., 1991). HCN from P. Fluorescens strain CHAO not repressed by fusaric acid played a significant role in disease suppression of $F$. oxysporum f.sp. Radicisly copersiciin tomato (Duffy et al., 2003).
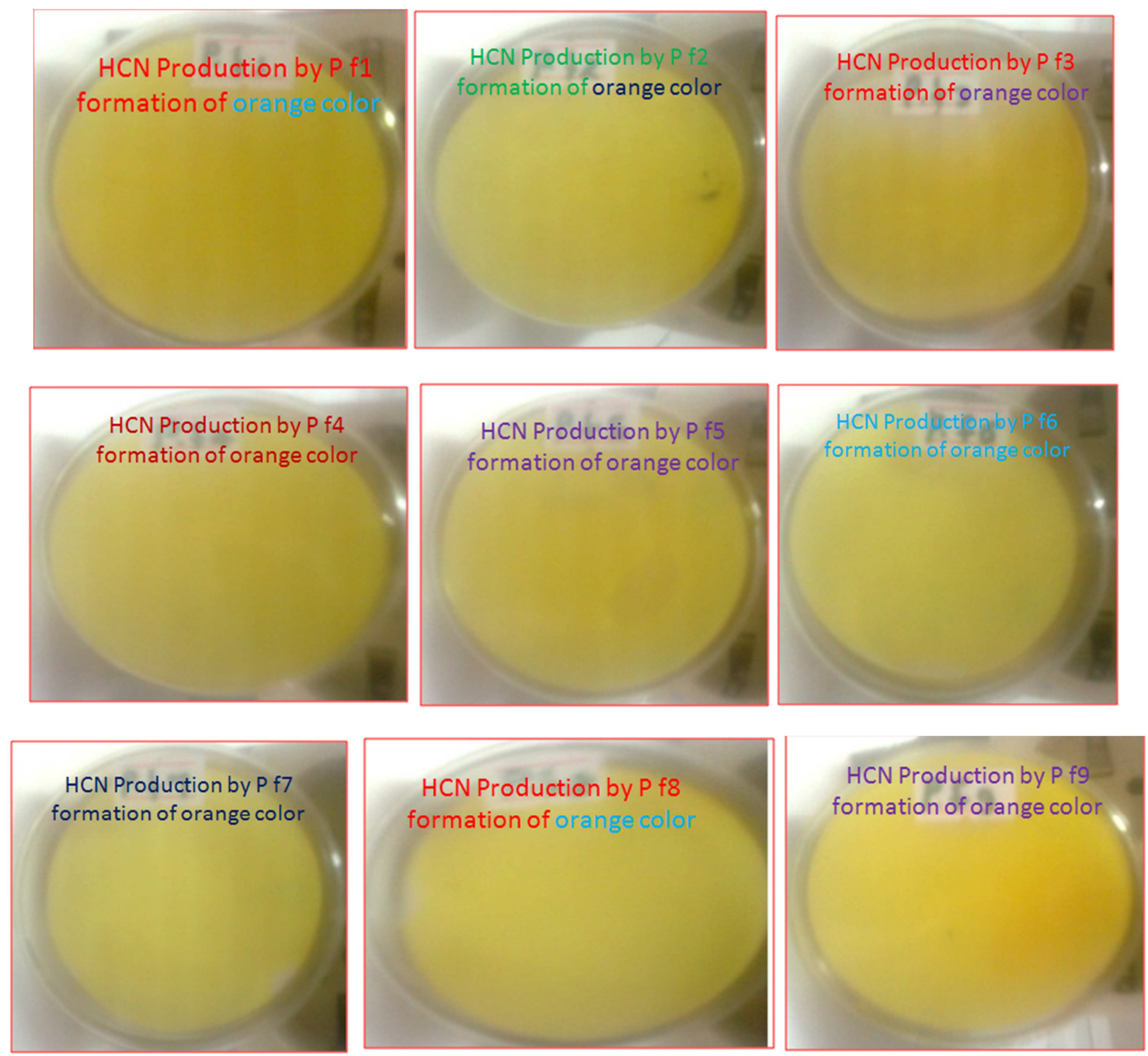

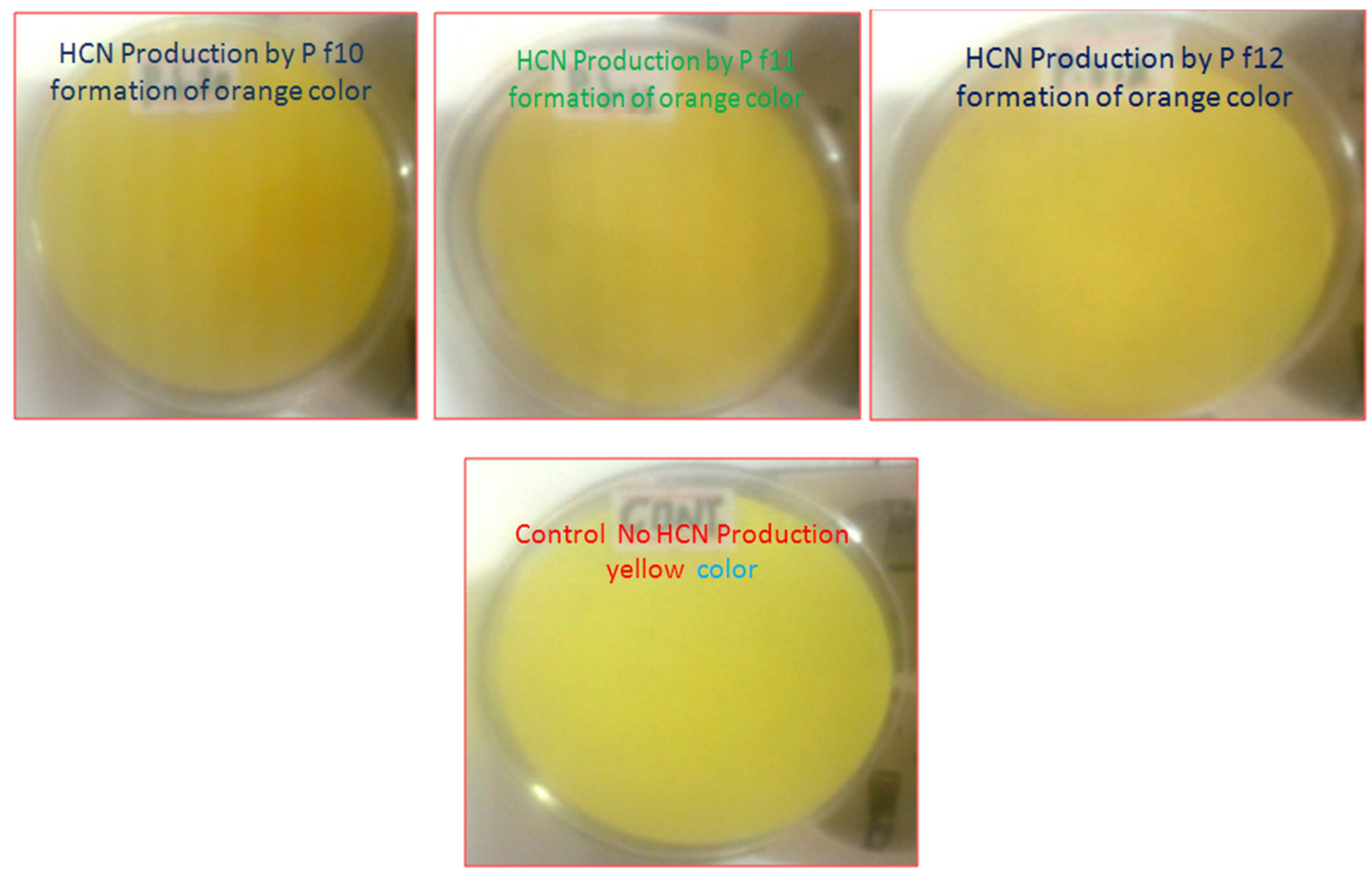

Figure 5. Hydrogen cyanide production by Pseudomonas fluorescens isolates was confirmed by a color shift from yellow to orange in the filter paper.

All Pseudomonas fluorescens isolates were positive for $\mathrm{HCN}$ production, which acts as an inducer of plant resistance. Ramettee et al. (2003) reported that hydrogen cyanide is a broadspectrum antimicrobial compound involved in biological control of root disease by many plant associated fluorescent pseudomonads. On other study, HCN is a secondary metabolite produced by gram negative $P$. fluorescens, $P$. aeruginosa, and Chromobacterium violaceum (Askeland and Morrison, 1983) and is postulated to play a role in biological control of pathogens (Defago et al., 1990). Pseudomonas spp. that showed remarkable inhibitory effects against the test fungal pathogens produced HCN (Muleta et al., 2007). This compound, although reported as a potential inhibitor of enzymes involved in major plant metabolic processes (Bakker and Schippers, 1987 ) is currently attracting remarkable attention and wide applications in areas of biocontrol methods. HCN production by rhizobacteria has been postulated to play an important role in the biological control of pathogens (Voisard et al., 1989). A leaf colonizing Pseudomonas sp. constructed to over produce $\mathrm{HCN}$ protected wheat from a leaf pathogen, Septocia tritici more effectively than the parent strain (Flaishman et al., 1996).

\section{Conclusion}

Based on the present study, all isolate of Pseudomonas fluorescens species possessing multiple mechanisms of broad spectrum antagonism traits that help as the best biocontrol agent against crop phytopathogens. Therefore, these isolate have a good tendency to remove plant pathogen through production of Hydrogen cyanide molecule.

\section{Acknowledgments}

I am grateful thanks to Addis Ababa University, Department of Microbial, Cellular, and Molecular Biology, College of Natural Sciences which are giving facilities to conduct this study.

\section{References}

[1] Antoun, H., Beauchamp, C. J., Goussard, N., Chabot, R. and Lalande, R. (1998). Potential of Rhizobium and Bradyrhizobium species as a plant growth promoting rhizobacteria on non legumes. Plant Soil 204: 57-67.

[2] Askeland, R. A. and Morrison, S. M. (1983). Cyanide production by Pseudomonas fluorescens and Pseudomonas aeruginosa. Appl. Environ. Microbiol. 45: 1802-1807.

[3] Bakker, A. W. and Schippers, B. (1987). Microbial cyanide production in the rhizosphere in relation to potato yield reduction and Pseudomonas spp. mediated plant growth stimulation. Soil Biol. Biochem.19: 451-457.

[4] Bano, N. and Musarrat, J. (2003). Characterization of a new Pseudomonas aeruginosa strain $\mathrm{NJ}-15$ as a potential biocontrol agent. Curr Microbiol 46: 324-328.

[5] Castric, P. (1977). Glycine metabolism of Pseudomonas aeruginosa: Hydrogen cyanide biosynthesis. J. Bacteriol.130: 826-831.

[6] Castric, P. A. (1975). Hydrogen cyanide, a secondary metabolite of Pseudomonas aeruginosa. Can. J. Microbiol. 21: 613-618.

[7] Cheeke, P. R. (1995). Endogenous toxins and mycotoxins in forage grasses and their effects on livestock. J Ani Sci 73: 909-918. 
[8] Corbett, J. R., (1974). Pesticide design. In: The Biochemical Mode of Action of Pesticides, Academic Press, Inc., London, pp.44-86.

[9] Defago, G., Berling, C. H., Borger, U., Keel, C. and Voisard, C. (1990). Suppression of black rot of tobacco by a Pseudomonas strain: Potential applications and mechanisms. In: Biological Control of Soil Borne Plant Pathogen, pp. 93108, (Hornby, D., Cook, R. J. and Henis, Y., eds). CAB International, Wellingford.

[10] Defago, G., Berling, C. H., Burger, U., Haas, D., Kahr, G., Keel, C., Voisard, C., Wirthner, P. and Wuthrich, B. (1990). Suppression of black root rotof tobacco and other root diseases by strains of Pseudomonas fluorescnes: Potential applications and mechanisms. In: Biological Control of Soil Borne Plant Pathogens (Ed. D. Hornby) CAB International, Wallingford, Oxon, UK, pp.93-108.

[11] Duffy, B., Schouten, A. and Raajimakers, J. (2003). Pathogen selfdefense: mechanisms to counteract microbial antagonism. Annu. Rev. Phytopathol., 45: 501-538.

[12] Dwived, D. and Johri, B.N. (2003). Antifungals from fluorescent pseudomonads: biosynthesis and regulation. Curr Sci. 85:1693-1703.

[13] Ebbs, S. (2004). Biological degradation of cyanide compounds. Curr Opin Biotechnol 15: 231-236.

[14] Flaishman, M. A., Eyal, Z., Zilberstein, A., Voisard, C. and Haas, D. (1996). Suppression of Septoria triticiblotch and leaf rust of wheat by recombinant cyanide producing strains of Pseudo-monas putida. Mol. Plant-Microbe Interact. 9: 642645 .

[15] Gehring, P. J., Mohan, R. J. and Watamare, P. G., (1993). Solvents, fumigants and related compounds. In: Handbook of Pesticide Toxiocology, Vol. 2, Eds., Hayes, W.J. and Laws, E.R., Academic Press, inc., San Diego, California, pp. 646649 .

[16] Guo, Y., Zheng, H., Yang, Y. and Wang, H. (2007). Characterization of Pseudomonas corrugata strain $\mathrm{p}_{94}$ isolated from soil in Beijing as a potential bicontrol agent. Curr. Microbiol. 55: 247-253.

[17] Keel, C., Voisard, C., Berling, C. H., Kahr, G. and Defago, G. (1989). Iron sufficiency, a pre-requisite for the suppression of tobacco black root rot by Pseudomonas fluoresens strain CHAO under gnobiotic conditions. Phytopathol. 79: 584-589.

[18] King, E. O., Ward, M. K. and Raney, D. E. (1954). Two simple media for the demonstration of pyocyanine and fluorescein. J. Lab. Clin. Med., 44: 301-307.

[19] Lorck, H. (1948). Production of hydrocyanic acid by bacteria. Physiol. Plant 1: 142-146.

[20] Luque-Almagro, V. M., Huertas, M. J., Martinez-Luque, M., Moreno-Vivian, C., Roldan, M. D., Garcia-Gil, L. J., Castillo, F. and Blasco, R. (2005). Bacterial degradation of cyanide and its metal complexes under alkaline conditions. Appl Environ Microbiol 71(2): 940-947.

[21] McMahon, J. M., White, W. L. B. and Sayre, R. T. (1995). Cyanogenesis in cassava (Manihot esculantaCrantz). J Exp Bot 46: 731-741.

[22] Muleta, D., Assefa, F.and Granhall. U. (2007). In vitro Antagonism of rhizobacteria isolated from Coffea arabica $\mathrm{L}$. against emerging fungal coffee pathogens. Eng. Life Sci.7: 577-586.

[23] Nagarajkumar, M., Bhaskaran, R. and Velazhahan, R. (2004). Involvement of secondary metabolites and extracellular lytic enzymes produced by Pseudomonas fluorescens in inhibition of Rhizoctonia solani, the rice sheath blight pathogen. Microbiol. Res. 159: 73-81.

[24] O'Sullivan, D. J. and O'Gara, F. (1992). Traits of fluorescent Pseudomonas spp. involved in suppression of plant root pathogens. Microbiol. Rev. 56: 662-676.

[25] Raaijmakers, J. M., Vlami, M. and de Souza, J. T. (2002). Antibiotic production by bacterial biocontrol agents. Int. J. Gen. Mol. Microbiol. 81: 537-547.

[26] Ramatte, A., Frapolli, M., Defago, G. and Moenne-Loccoz, Y. (2003). Phylogeny of HCN synthase encoding henbcgenes in biocontrol fluorescent pseudomonads and its relationship with host plant species and HCN synthesis ability. Molecular Biol.. Pl. Microbe Interaction 16: 525-535.

[27] Rangajaran, S., Saleena, L. M., Vasudevan, P. and Nair, S. (2003). Biological suppression of rice diseases by Pseudomonas spp. under saline soil conditions. Plant Soil 251: $73-82$.

[28] Sacherer, P., Défago, G. and Haas, D. (1994). Extracellular protease and phosholipase $\mathrm{C}$ are controlled by the global regulatory gene gacA in the biocontrol strain Pseudomonas fluorescens CHA0. F. E. M. S. Microbiol. Lett. 116: 155-160.

[29] Shivakumar, B. (2007). Biocontrol Potential and Plant Growth Promotional Activity of Fluorescent Pseudomonads of Western Ghats, M.Sc. Thesis. Dharwad University of Agricultural Sciences, Dharwad.

[30] Siddiqui, I. A., Shaukat, S. S., Khan, G. H. and Ali, N. I. (2003). Supperssion of Meloidogyne javanica by Pseudomonas aeruginosa IE-6S+ in tomato: the influence of $\mathrm{NaCl}$, oxygen and iron level. Soil Biol. Biochem. 35: 16251634 .

[31] Siddiqui, I.A., Shaukat, S. S., Sheikh, I. H. and Khan, A. (2006). Role of cyanide production by Pseudomonas fluorescens $\mathrm{CHAO}$ in the suppression of root-knot nematode, javanica in tomato. World J. Microbiol. Biotechnol. 22: 641650.

[32] Stutz, E.W., Defago, G. and Kern, H. (1986). Naturally occurring fluorescent pseudomonads involved in suppression of black root rot of tobacco. Phytopathol. 76: 181-185.

[33] Voisard, C., Bull, C. T., Keel, C., Laville, J., Maurhofer, M., Schnider, U., De'fago, G. and Haas, D. (1994). Biocontrol of root diseases by Pseudomonas fluorescens CHAO: current concepts and experimental approaches. In: Molecular Ecology of Rhizosphere Microorganisms: Biotechnology and the Release of GMO's, pp. 67-89, (O'Gara, F., Dowling, D. N. and Boesten, B., eds). VCH, Weinheim.

[34] Voisard, C., Keel, C., Haas, D. and Defago, G. (1989). Cyanide production by Pseudomonas fluorescens helps suppress black root rot of tobacco under gnotobiotic conditions. EMBO J., 8: 351-358.

[35] Wangi, F. M., Hauschild, R., Sokora, R.A. and Mutitu, E. (2002). Challenges to Organic Farming and Sustainable Land Use in the Tropics and Subtropics. Deutschea Tropentag, Witzenhausen. 
[36] Wei, G., Kloepper, J. W. and Tuzun, S., 1991, Inductionof systemic resistance of cucumber to Colletotrichum orbiculareby selected strains of plant growth promoting rhizobacteria. Phytopathol., 81: 1508-1512.

[37] Weller, D. M. (1985). Application of fluorescens Pseudomonas to control root diseased. In: Ecology and Management of Soil Borne Plant Pathogens, pp.137-140, (Purker, C. S., Roura, A. D., Moore, K. J., Wang, P. T. W. and
Kellmorgan J. F., eds). American Phytopathological Society, St. Paul.

[38] Weststeijn, W. A. (1990). Fluorescent pseudomonads isolate E11-2 as biological agent for Pythium root rot in tulips. Netherlands J. Pl. Pathol., 96: 262-272.

[39] Zagrobelny, M., Bak, S. and Moller, B. L. (2008). Cyanogenesis in plants and arthropods. J Phytochem 69: 1457-1468. 